\title{
Grammatical Errors Made by Eighth-Grade Students in Speaking English
}

\author{
Merliyani Putri Anggraini', Satria Adi Pradana² \\ Universitas Negeri Malang ${ }^{1}$, UIN Raden Intan Lampung ${ }^{2}$ \\ satriaadhipradana@radenintan.ac.id
}

\begin{abstract}
This research is primarily concerned with the analysis of grammatical errors. It discusses the grammatical errors made by eighth-grade students in their speaking abilities. The data of the study are the conversation of the students that are defined into ten groups. The grammatical errors are classified based on Comparative Taxonomy. They are; developmental errors, interlingual errors, ambiguous errors, and other errors. Besides classifying the errors, the research also discovers the sources of errors. A qualitative approach was employed to gather the data in this study. The result of this study shows that the students committed errors in every type of Comparative Taxonomy. The most error that students made was interlingual errors. It can be inferred that the student's mother tongue interfered with them in speaking English. Based on the observation and interview, the possible causes of students' grammatical errors were interlingual transfer, intralingual transfer, the context of learning, and communication strategy.
\end{abstract}

Keywords: comparative taxonomy; grammatical errors; speaking english

\section{INTRODUCTION}

It is not easy to speak and master English grammar for new English students since they face various circumstances. English is seldom used in everyday practices in Indonesia. Students typically use English while they are in the teaching and learning phase, for example, in the formal education situation. As a result, students usually make errors in speaking English. In addition, it can be difficult to speak with proper grammar in English due to the limitation of the time to practising the expression and lack of grammar and word organization. According to Dulay 
(1982:82), it is natural that L2 students commit errors. This suggests that the mistakes in the process of language learning are the indivisible aspect of students.

According to Chomsky, as quoted by Dulay (1982), errors result from a lack of knowledge of the language rules. It means that the students do something that should not happen but without realizing it. Especially in a conversation or speaking, it usually occurs when the students do not understand the use of grammar. In this case, he classifies the categories of error analysis into four kinds of taxonomy named Linguistic Category Taxonomy, Surface Strategy Taxonomy, Comparative Taxonomy, and Communicative Effect Taxonomy. Each category has a different way of classifying or identify the errors that the learners make.

Errors in foreign language teaching, especially in English, are among the most complicated to prevent. All students must inevitably make mistakes and commit errors. However, the process can be hindered by recognizing mistakes and correcting them based on the feedback received. As per Corder (1981) and Norish (1983), errors may occur due to human factors in learning the target language, such as memory limitations, psychological issues, and misunderstandings about the subject content. On the other hand, students do not understand their mistakes or are unaware that they have made errors. As a consequence, errors must be treated favourably. Error analysis (EA) and suitable correcting strategies may also help with successful English learning and teaching (Darus, 2009).

In spite of this fact, many teachers try to only analyze the errors without paying attention to the sources of the errors. Nevertheless, it is also essential 
to find out the sources because the teacher has to know why his students commit the errors found in writing and speaking of second and foreign language learners (Richard, 1974). Teachers who can effectively analyze and handle errors are more able to make their students become more knowledgeable of their own errors. Krishnamy (2015) further discovered that error analysis allows teachers to identify the causes of mistakes and take pedagogical steps to avoid them. Consequently, analyzing learner language has been crucial in resolving specific issues and proposing solutions to various concerns.

Furthermore, referring to Chomsky, as quoted by Dulay (1982), that errors are classified into four kinds of taxonomy named Linguistic Category Taxonomy, Surface Strategy Taxonomy, Comparative Taxonomy, and Communicative Effect Taxonomy. Each category has a different way to identify, classify, and analyze the errors that are made by the learners. There are some previous studies that classified and identified the errors by using Linguistic Category Taxonomy and Surface Strategy Taxonomy (Darus, 2009, Kovac, 2011, Sokeng, 2014, Nonkukhetkhong, 2013 Thomas, 2014). On the other hand, the researchers are interested in analyzing the errors using different taxonomy, Comparative Taxonomy. They wanted to know the different classifications of errors by using this taxonomy because it classifies the errors affected by students' mother tongue and language development (Dulay, 1982). In short, the researcher formulated the problem as follows:

1. What types of grammatical errors are made by the students in speaking English based on Comparative Taxonomy? 
2. What are the sources of the students' grammatical errors in speaking English?

\section{METHODS}

The population of this study consisted of 38 eighth-grade students from a junior high school in Indonesia. The students consisted of 21 males and 17 females. They were asked to participate in making English conversations. The researcher analyzed the grammatical errors that the students committed to doing conversation using English. The topic of conversation was taken by the topic they have learned before. It was about "Daily Activity."

The key instrument in collecting the data was the researcher. The researcher observed the activities that lasted during her research as the nonparticipant observer and recorded two conversations. After collecting the data, the researcher identified, classified, and analyzed the errors based on Comparative Taxonomy (developmental errors, interlingual errors, ambiguous errors, and other errors), and investigated the sources. The conversation was recorded by the researcher. Afterwards, she transcribed the data and analyzed them.

To answer the first research question, the researchers employed descriptive statistics to know the types of errors made by the students. Finally, to unveil the sources of errors that were caused students to make errors, they were interviewed and asked whether they could analyze their own errors. It aims at differentiating the concept of mistakes and errors. 


\section{RESULT AND DISCUSSION}

Result

The researcher described the data that had already been divided into four categories of Comparative Taxonomy. By grouping the errors, they were able to identify the data. Developmental errors, interlingual errors, undefined errors, and other errors are the four forms of Comparative Taxonomy.

The researcher calculated the percentage of each mistake made by the students when conversing in English.

Table 1. The Proportion of Students' Grammatical Errors in Speaking English

\begin{tabular}{|c|l|c|c|}
\hline No & \multicolumn{1}{|c|}{ Types of Errors } & Frequency & Percentage \\
\hline 1 & Developmental Errors & 14 items & $33.33 \%$ \\
\hline 2 & Interlingual Errors & 18 items & $42.86 \%$ \\
\hline 3 & Ambiguous Errors & 3 items & $7.14 \%$ \\
\hline 4 & Other Errors & 7 items & $16.67 \%$ \\
\hline & Total & 42 items & $100 \%$ \\
\hline
\end{tabular}

As we can see in Table 1, most students make grammatical errors at the level of interlingual errors $(42.86 \%)$. The second was developmental errors with a percentage of $33.33 \%$. Other errors were the third error that the students made (20\%), moreover ambiguous errors became the last error that the minor students made respectively $(10 \%)$. 


\section{Discussion}

The researcher would like to analyze the findings of the study of grammatical errors in speaking English produced by eighth-grade students in this section.

\section{Types of the Students' Grammatical Errors in Speaking English}

Based on Comparative Taxonomy, the following are some examples of students' grammatical mistakes in speaking English. Developmental errors, interlingual errors, ambiguous errors, and other errors are the four classifications of Comparative Taxonomy predicated on Dulay (1982).

\section{1) Developmental Errors}

Dulay (1982) emphasised that developmental errors are made by children who are not native speakers of the target language. . The omission of the article and the past tense indicator by the students were listed as developmental in this study since these are often included in children's speech studying English as a first language. The following information depicted examples of errors made by students while speaking English.

Student 1 : What do you do in the evening?

Student 2 : I prepare study. *(I prepare to study)

Dulay states that this type of error is also made by the children who learn English as their native language. In the data display, developmental errors are in the second position with $33.33 \%$. It means there are still many students who made errors by omitted the article and some other grammatical rules. They may not know the 
function of constructing an English sentence or utterance. For example, most of them ignored putting an article in their conversation, whereas an article is helpful to tell about the noun, which aimed to discuss by the speakers.

\section{2) Interlingual Errors}

Based on Dulay (1982), interlingual errors are caused by the intrusion of L1 into L2. In this case, the student's mother tongue creates issues for the students to learn a foreign language. The following details represent examples of errors made by students when performing the conversation:

Student 1 : What do you do in the afternoon?

Student 2 : I ready to lunch. *(I am ready to have lunch.)

Interlingual errors are the errors that mostly the students committed. From 42 items, interlingual errors got 18 items with a percentage of $42.86 \%$. The students' mother tongue influences them in speaking English. They assume that the structure in their first language is similar to the English structure. Because interlingual errors are the most error made by the students, the teacher should give the students clear explanation that English structure is different from the students' first language and cannot translate a sentence or an utterance into English without knowing its structure.

\section{3) Ambiguous Errors}

According to Dulay (1982), ambiguous errors may be classified as developmental or interlingual. This is due to the fact that these errors illustrate the student's natural language structure while still being similar to those found in the 
speech of children learning a first language. The errors are represented by the following data:

Student 1 : What do you do in the evening?

Student 2 : I read book English. *(I read an/the English book.)

Based on ten conversations that had been recorded, among forty-two items, ambiguous errors had three items. In addition, ambiguous errors are the fewest errors that the students made in conversation (7.14\%). It means only three students who made this type of errors. Dulay classifies these errors as they indicate the learner's native language structure while still being of the form seen in the speech of children learning a first language. In this case, the students made two types of errors at once, and the errors could be classified as developmental errors and interlingual errors.

\section{4) Others Errors}

Others errors, also known as notable errors, are total without a grab bag for items that do not fall into any other type (Dulay, 1982). The following data are instances of errors made by students during the conversation.

Student 1 : What's do you do in the early morning? *(What do you do in the early morning?

Student 2 : I wake up from the bedroom in the early morning. What about you?

The last errors made by the students are other errors. Tarigan (1990) explains that the type of errors cannot be ignored by the researchers because it can be a view or an idea that may become an interesting part for the researcher in analyzing the 
errors. In line with Tarigan, Dulay (1982) outlined that a study of such errors could provide valuable insights into specific differences in the organization of linguistic input. They are those, which do not fit in any of the categories mentioned above of this taxonomy. Based on those theories, the researcher found the students made 6 items in percentage $16.67 \%$ of 42 items. Other errors are also known as unique errors.

Sources of the Students' Grammatical Errors in Speaking English.

The researchers did several steps in discovering the causes of the errors caused by the students, such as recognizing, classifying, and evaluating the categories of errors. The causes of errors are some of the reasons that lead to students making mistakes. Interlingual transfer, intralingual negative transfer, the meaning of learning, and learning context are the four types defined by Brown (2000). The researcher classified them by drawing a table to uncover the causes of errors clearer. The table below provides an illustration of error source analysis.

Brown (2000) outlined four leading causes of errors: interlingual transfer, intralingual transfer, learning context, and communication strategy. The study observed four types of sources that caused students to make grammatical errors while speaking English based on the data.

\section{1) Interlingual Transfer}

There is a lot of interlingual transfer in the early stages of acquiring a second language (from the native language). Interlingual transfer, as stated by Brown 
(2000:224), is the use of patterns from the mother tongue. The following are the examples of this source when the students speaking English:

\section{a. Student 1 : What do you do in the night? *in the evening}

Student 2 : I prefer study.

b. Student 1 : What do you do in the afternoon?

\section{Student 2 : I wash plate. *dishes}

The examples above have interferences from the pattern of the student's mother tongue, Bahasa Indonesia. In example (a), it is incorrect because there is a wrong perception. Mostly, the student will think that malam in Bahasa is night in English, whereas night time in English is the time for sleeping. Related to the utterance, it should be "evening", that related to that utterance. The example (b), the word plate in English is piring in Bahasa Indonesia. It is not wrong when the speaker say it in another context. For this context, the appropriate word for piring is dish because commonly, the native speaker does not say literally washing plate, but the correct one is washing dishes.

\section{2) Intralingual Transfer}

Intralingual intervention, based on Brown (2000), is described as the negative transfer of elements within the target language or looking at it another way, the inaccurate generalization of rules within the target language. There are examples of the intralingual transfer (overgeneralization) when the students made English conversation:

\section{a. Student 1 : When do you can study?}


Student 2 : I study at $19.00-21.00$.

\section{b. Student 1 : Where you watch television?}

Student 2 : In my house.

c. Student 1 : What do you do in the afternoon?

Student 2 : I ready to lunch.

Those examples above have overgeneralization rules. The example a, the student wanted to say kapan kamu bisa belajar without knowing how to construct a good sentence in English. He translated directly before knowing the correct pattern. The example b, the student did not put $d o$ in the utterance. In English structure, we have to know how to construct an excellent interrogative sentence. If there is no modal "do" in that sentence, it means the utterance is a statement and not an interrogative sentence. Meanwhile, in example c, the speaker made an error while answering the question. He aimed to say saya siap untuk makan siang. It can be inferred that the students have made errors in interlingual transfer because of negative interference of the mother tongue. Therefore, there must be to be am and put in predicate between to and lunch. These errors may come from the incorrect generalization of rules within the target language.

\section{3) Context of Learning}

According to Brown, the context of learning is another cause of mistakes. The classroom with their instructor and the materials in the form of untutored by the teacher is referred to as the learning context. Students often make mistakes as a result of a teacher's misinformation, a textbook's incorrect presentation of word 
structure, or even a pattern that was memorized in drill yet not adequately contextualized.

As students make mistakes in English speech, it indicates that they are making mistakes in their studying. It could result from teachers deceiving students while teaching and learning in the classroom or from students reading textbooks on their own while studying. Centered on the students' English talk, there are several explanations of context of learning as a source of errors:

a. Student 1 : What do you do in the evening?

Student 2 : I reading book.

b. Student 1 : What do you do after wake up?

Student 2 : I clean bed.

c. Student 1 : What do you do in the early morning?

Student 2 : I wake up from the bedroom in the early morning.

The question should be asked in a verbal speech, and the response should be given in a verbal speech as well. In this case, student 2 mentioned that he was reading a book, while student 1 inquired verbally using "Simple Present Tense." If 'am' was added to this statement, it would become "Simple Present Continuous Tense." He is demanded to omit -ing after read, which is the correct one.

In illustration b, the student made an error in the sentence "after wake up." It should be revised as "after waking up". Since "after" is a preposition in this utterance, it must be accompanied by "gerund." "Wake up," on the other hand, is not a gerund form. He should modify the form to gerund in order to transform it into a noun. A 
gerund is a word that ends in -ing and is formed from a verb. It is used in the same way as a noun. As a result, the right one is waking up.

The incorrect one in example $\mathrm{c}$ of this source is the perception between wake up and get up. Learners, who learn English as a foreign language, such as in Indonesia, have a perception that wake up means get out of the bed. Even though, wake up means become conscious after sleeping. If they want to say get out of bed, they may use get up instead of wake up. In addition, they do not need to put from the bed or bedroom after get up, because get up already means so without that phrase.

\section{4) Communication Strategy}

When people's language structures are not easily accessible to the learner at a stage of the conversation, a communication strategy is the deliberate use of verbal or nonverbal mechanisms for expressing a concept. When the students use language, they may have some strategies that are used in their communication, both verbal and nonverbal. Here are the examples of students' grammatical errors caused by communication strategy based on the students' English conversation:

a. Student $1 \quad$ : What time do you help mother?

Student 2 : I help mother are delapan until sepuluh o'clock.

b. Student 1 : I play football, what about you?

\section{Student 2 : Clean the room.}

c. Student $1 \quad$ : I play football, what about you?

\section{Student 2 : I PlayStation.}


In example a, it shows that the student 2 did not know how to say delapan and sepuluh in English, so he switched it into his native language, Bahasa, to make the listener understand what he meant. It is an error caused by communication strategy. On the other hand,

Error in example b is the student did not insert the subject in that utterance. So, it makes the utterance become ambiguous. The first one can be a statement, and the second one can be an imperative utterance. In Bahasa, the utterance without subject is allowed, the listener can still get the meaning of what the speaker says, but in English, the utterance without subject can turn into ambiguous. In English utterance, the speaker either has to put the subject or an imperative utterance. It means the speaker has to put the subject in that utterance to clarify what the speaker says.

Error in example c is committed by student 2. He might consider that "PlayStation" was already a verb, whereas it is only a noun. "PlayStation" means a series of video game consoles. If he did not construct the utterance syntactically, it means the listener also didn't get the meaning. Therefore, he had to add a verb before "PlayStation." 


\section{CONCLUSION}

Primarily focused on Comparative Taxonomy, this study describes the students' grammatical errors while speaking English. Under Comparative Taxonomy, there are four categories of errors: developmental errors, interlingual errors, ambiguous errors, and other errors. Interlingual errors were the most common errors made by many students in English conversations. The invasion of L1 into L2 is said to cause errors. In this situation, the learner's mother tongue makes it difficult to learn a foreign language. It can be inferred that the student's mother tongue hampered their ability to learn English, especially when it came to speaking.

After examining and exploring the study's findings, the researcher seeks to contribute the study's findings to more effective English teaching. It is almost as critical to correct errors as it is to identify and describe them. Not only should educators look for errors, but they should also scrutinise the sources. This would aid them in comprehending the factors that contribute to student errors.

\section{REFERENCES}

Brown, H. D., (2000), Principles of Language Learning and Teaching (Fourth Edition), London: Longman

Corder, S. P., (1981), Error Analysis and Interlanguage, London: Oxford University Press 
Darus, S., (2009). Error Analysis of the Written English Essays of Secondary School Students in Malaysia: A Case Study. In European Journal of Social Sciences Volume 8 - No.3. pp. 483-495.

Dulay, H., et.al, (1982), Language Two, New York: Oxford University Press

Krishnasamy, J., (2015). Grammatical Error Analysis in Writing of ESL Diploma Students. In Asian Journal of Education and e-Learning (ISSN: 2321 2454) Volume 03 - Issue 01. pp. 51-60.

Kovač, M. M., (2011). Speech Errors in English as Foreign Language: A Case Study of Engineering Students in Croatia. In English Language and Literature Studies Vol. 1, No. 1 doi:10.5539/ells.v1n1p20

Nonkukhetkhong, K., (2013). Grammatical Error Analysis of the First Year English Major Students, Udon Thani Rajabhat University. In The Asian Conference on Language Learning Official Conference Proceedings 2013, pp. 117-127.

Norrish, J., 1983, Language Learner and Their Errors, London: Macmillan

Pollard, L, (2008). Teaching English, London: Lucy Pollard Copyright.

Richards, J. C., (1974), Error Analysis: Perspective on Second Language Acquisition, London: Longman

Sokeng, S. C. P., (2014). Grammatical Errors of Bilingual 1 Francophone Learners of English in the University of Yaounde I. In Theory and Practice in Language Studies, Vol. 4, No. 9, pp. 1778-1785. 
English Education: Jurnal Tadris Bahasa Inggris pISSN 2086-6003 | eISSN 2580-1449 Vol. 14 (1), 2021 30-46

Tarigan, H. G. and Djago Tarigan, (1990), Pengajaran Analisis Kesalahan Berbahasa, Bandung: Angkasa

Thomas, J., (2014). Case Study of Error Analysis of the Usage of Tense in English by I Year Engineering Students From Tamil Medium Schools. In IMPACT: International Journal of Research in Humanities, Arts and Literature Vol. 2 Issue 3, pp. 47-52. 